University of Nebraska - Lincoln

DigitalCommons@University of Nebraska - Lincoln

Nebraska Cooperative Fish \& Wildlife Research Nebraska Cooperative Fish \& Wildlife Research Unit -- Staff Publications

2007

\title{
Breeding Biology of Passerines in a Subtropical Montane Forest in Northwestern Argentina
}

\author{
Sonya K. Auer \\ University of Montana \\ Ronald D. Bassar \\ University of Montana \\ Joseph J. Fontaine \\ University of Montana, jfontaine2@unl.edu \\ Thomas E. Martin \\ University of Montana, tom.martin@umontana.edu
}

Follow this and additional works at: https://digitalcommons.unl.edu/ncfwrustaff

Part of the Other Environmental Sciences Commons

Auer, Sonya K.; Bassar, Ronald D.; Fontaine, Joseph J.; and Martin, Thomas E., "Breeding Biology of Passerines in a Subtropical Montane Forest in Northwestern Argentina" (2007). Nebraska Cooperative Fish \& Wildlife Research Unit -- Staff Publications. 2.

https://digitalcommons.unl.edu/ncfwrustaff/2

This Article is brought to you for free and open access by the Nebraska Cooperative Fish \& Wildlife Research Unit at DigitalCommons@University of Nebraska - Lincoln. It has been accepted for inclusion in Nebraska Cooperative Fish \& Wildlife Research Unit -- Staff Publications by an authorized administrator of DigitalCommons@University of Nebraska - Lincoln. 


\title{
BREEDING BIOLOGY OF PASSERINES IN A SUBTROPICAL MONTANE FOREST IN NORTHWESTERN ARGENTINA
}

\author{
Sonya K. Auer ${ }^{1}$, Ronald D. Bassar, Joseph J. Fontaine, And \\ THOMAS E. MARTIN \\ U.S. Geological Survey, Montana Cooperative Wildlife Research Unit, University of Montana, \\ Missoula, MT 59812
}

\begin{abstract}
The breeding ecology of south temperate bird species is less widely known than that of north temperate species, yet because they comprise a large portion of the world's avian diversity, knowledge of their breeding ecology can contribute to a more comprehensive understanding of the geographic diversity of avian reproductive traits and life history strategies. We provide the first detailed examination of the reproductive strategies of 18 forest passerines of subtropical, northwestern Argentina. Mean clutch sizes were smaller and egg mass was greater than for north temperate birds, but differed among species and nest types, with cavity-nesters having larger clutches than species with opencup and enclosed nests. Across all species, the average breeding season duration was 50 days; thus, the common perception that southern species have smaller clutch sizes because of longer breeding seasons is not supported in this community. Daily nest predation rates were influenced by nest type, cavity nests suffering the least from predation, as found in north temperate systems. Only females incubated eggs in all but one species, whereas both parents fed and cared for nestlings in all species. Mean nest attentiveness was low compared to north temperate passerines. Mean hourly nestling feeding rates differed among species and were negatively related to nest predation risk. In short, coexisting species in this subtropical forest varied in their life history strategies, in part correlated with variation in nest predation risk, but also differing from north temperate species.
\end{abstract}

Key words: Argentina, breeding biology, life history, passerines, Yungas forest.

\section{Biología Reproductiva de Aves en un Bosque Subtropical Montano del Noroeste de Argentina}

Resumen. La biología reproductiva de aves del hemisferio sur es menos conocida que la de las del hemisferio norte. Dado que las aves del hemisferio sur comprenden una gran parte de la diversidad de especies de aves, su conocimiento contribuye a entender mejor la diversidad geográfica de su biología reproductiva y de sus estrategias de historias de vida. Aquí brindamos el primer estudio detallado sobre las estrategias reproductivas de 18 especies de aves canoras del noroeste subtropical de Argentina. El tamaño promedio de la nidada fue menor y el peso de los huevos fue mayor que el de las aves de las zonas templadas del hemisferio Norte. Estos parámetros también fueron diferentes entre especies y tipos de nido, siendo los nidos en cavidades los que presentaron nidadas más grandes, en comparación con los nidos en forma de taza abierta y cerrada. En promedio, para todas las especies de esta comunidad, la temporada reproductiva duró 50 días, lo cual debilita la percepción común de que las aves del sur tienen nidadas más pequeñas debido a temporadas reproductivas más largas. La tasa de depredación diaria estuvo influenciada por el tipo de nido, siendo los nidos en cavidades los que sufren la menor depredación, al igual que en el hemisferio norte. Con excepción a una especie, en todas las especies la hembra es la única que incuba, mientras que ambos padres alimentan y cuidan a los polluelos. El promedio de atención al nido fue bajo en comparación con las aves canoras del hemisferio norte. La tasa promedio de alimentación de polluelos por hora varió entre especies y estuvo negativamente correlacionada con el riesgo de depredación. En conclusión, las especies que coexisten en este bosque subtropical varían en sus estrategias de historia de vida en correlación con el riesgo de depredación de los nidos, y también difieren de las especies de las zonas templadas del hemisferio Norte.

\footnotetext{
Manuscript received 6 April 2006; accepted 10 January 2007.

${ }^{1}$ Present address: Department of Biology, University of California, Riverside, CA 92521. E-mail: myioborus@yahoo.com
} 


\section{INTRODUCTION}

Understanding the causes and consequences of variation in reproductive strategies is a major focus of avian life history studies (Martin 1987, Roff 1992, Stearns 1992). Detailed breeding biology descriptions are fundamental to understanding variation in avian reproductive strategies because they provide critical natural history data that describe patterns of variation and facilitate the generation of new hypotheses and testing of older ones. Reproductive traits of many north temperate bird species are well documented, and these descriptions have contributed much to the development and testing of life history theory (Roff 1992, Stearns 1992). Tropical and south temperate birds comprise a large portion of the world's total diversity (Fischer 1960), yet knowledge of their reproductive ecology is still limited (Martin 1996, 2004). Bird species in South America, in particular, account for more than $30 \%$ of the world's avian diversity, but the breeding biology of many of these species has not been described in detail (Ridgely and Tudor 1989, 1994).

Studies of tropical and south temperate species can contribute to a more comprehensive understanding of the geographic diversity of avian reproductive traits and life history strategies (Skutch 1985, Martin et al. 2000). For example, latitudinal gradients in clutch size are well documented, and understanding this geographic variation has been the focus of decades of life history research (Skutch 1985, Kulesza 1990, Yom-Tov et al. 1994, Martin 1996). Other components of reproduction, such as developmental rates and parental behaviors, also vary along latitudinal gradients, but the extent to which these traits vary among coexisting species in southern regions is less widely known (Martin 2002, 2004). Thus, additional information on the breeding biology of tropical and southern hemisphere species would significantly aid advances in understanding geographic variation in avian life histories (Martin 2004).

Here, we provide the first detailed examination of the reproductive ecology of 18 bird species from six passerine families in a subtropical forest in northwestern Argentina. We report nest types and heights, nesting success, nest initiation dates, clutch size, egg mass and dimensions, adult body mass and tarsus lengths, nesting period lengths, and parental care behaviors. We also examine variation in breeding strategies among these species to facilitate broader comparisons with tropical and north temperate congeners.

\section{METHODS}

\section{STUDY AREA AND SPECIES ASSEMBLAGE}

Our study was conducted in El Rey National Park in the northwestern province of Salta, Argentina ( $26^{\circ} \mathrm{S}$ latitude). The park encompassed 44000 hectares and ranged in elevation from 700 to $2300 \mathrm{~m}$ above sea level. Mean annual temperature was $20^{\circ} \mathrm{C}$ (Bianchi 1981). Annual rainfall ranged from 1000 to $3000 \mathrm{~mm}$, with $80 \%$ of the rainfall occurring between November and March (Chalukian 1991). Twenty study plots, roughly 20 ha each, were located in the center of the park at 1000 to $2000 \mathrm{~m}$ elevation. The dominant ecosystem type at these elevations was Yungas forest, a semi-evergreen subtropical montane forest type that forms the southernmost of the Andean tropical forest types (Cabrera 1976, Cabrera and Willink 1980, Brown 1995). Dominant tree families in the park were Lauraceae, Myrtaceae, Fabaceae, Juglandaceae, and Nyctaginaceae (Grau 2000).

Avian species that we studied with sufficient sample sizes for estimating breeding biology parameters included: Buff-browed Foliagegleaner (Syndactyla rufosuperciliata), Smallbilled Elaenia (Elaenia parvirostris), Slaty Elaenia (Elaenia strepera), Mottle-cheeked Tyrannulet (Phylloscartes ventralis), Ochre-faced Tody-Flycatcher (Poecilotriccus plumbeiceps), Euler's Flycatcher (Lathrotriccus euleri), House Wren (Troglodytes aedon), Mountain Wren (Troglodytes solstitialis), Spotted NightingaleThrush (Catharus dryas), Slaty Thrush (Turdus nigriceps), Rufous-bellied Thrush (Turdus rufiventris), Rufous-collared Sparrow (Zonotrichia capensis), Saffron-billed Sparrow (Arremon flavirostris), Stripe-headed Brush-Finch (Buarremon torquatus), Masked Yellowthroat (Geothlypis aequinoctalis), Brown-capped Redstart (Myioborus brunniceps), Two-banded Warbler (Basileuterus bivittatus), and Pale-legged Warbler (Basileuterus signatus).

\section{NEST SEARCHING AND MONITORING}

We located and monitored nests from October to January in 1997 and 1998, and from October to December in 1999 . We found nests primarily 
by using parental behavioral cues, for example by observing parents bringing nesting material during building, returning to the nest to resume incubation, or carrying food to nestlings in the nest. We found a small proportion of nests by accidentally flushing an adult off the nest while walking past. Once found, we monitored nests every 2-4 days when no transition between nesting stages was expected. When a suspected stage transition approached, we monitored nests every 1-2 days to determine clutch size, lengths of developmental periods, and nest fate (Martin and Geupel 1993, Martin et al. 1996). We monitored low nests through direct observation of nest contents, while higher nests were checked either with a mirror on an extendable pole or by observing parental behavior at the nest. We waited for parents to leave the nest of their own accord before checking nest contents, and took great care not to approach a nest from the same direction during successive nest checks in an attempt to minimize disturbance in the area and prevent observer-induced nest predation.

\section{NEST TYPES AND HEIGHTS}

We recorded the type and height of each nest once the nest was no longer active. We measured the height of low nests with a meter stick $( \pm 1 \mathrm{~mm})$ and higher nests using a Suunto (Langley, British Columbia) clinometer. We classified nests as open-cup, enclosed, or cavity. Open-cup nests were cup-shaped constructions and were built on the ground, inside irregularities in logs, tree trunks, or banks, or in the branches of shrubs, trees, or vines. Enclosed nests included pendular or globular constructions with a side entrance that either hung from trees or vines or were built on the ground. Cavity nests were built primarily in naturally formed holes in the trunks or large branches of living trees or snags.

\section{NESTING SUCCESS}

We monitored nests to determine their fates during the laying, incubation, and nestling periods. We considered nests depredated if all eggs or young nestlings disappeared or if parental activity ceased during laying, incubation, or early in the nestling period. We considered nests to have successfully fledged young if fledglings were observed, if nestlings were seen in the nest within two days of their predicted fledging date, or if parents were seen carrying food in the vicinity of the nest. We calculated mean daily mortality rates due to all causes and mean daily mortality rates due to predation for species with more than 20 nests. Due to small sample sizes for some species and because we were interested in providing generalized estimates for species, estimates were pooled across all years. All mortality estimates were calculated for the incubation, nestling, and overall nesting stages following Mayfield (1961, 1975) and variance estimates following Hensler and Nichols (1981). We identified nest predators by serendipitously interrupting predation events during nest checks or when video footage of parental care behaviors (see below) caught predators in the act of taking nest contents.

\section{NESTING BIOLOGY}

We determined nest initiation dates either by observing the day the first egg was laid or by using known hatching dates with mean incubation period lengths and clutch sizes to extrapolate the day the first egg was laid. We calculated the breeding season length for each species by first pooling all initiation dates across years and then calculating the length of time represented by the middle $90 \%$ of the nests; the earliest and latest $5 \%$ of dates were excluded to reduce the effect that single early and late individual nesters might have on breeding season length estimates. We determined the mean breeding season start date for each species by calculating the mean date of $10 \%$ of the earliest nests for each species in each year and averaging across years. We pooled estimates of the start and length of the breeding season across years due to low sample sizes.

We recorded clutch size as the maximum number of eggs observed in a nest during two consecutive visits immediately following the end of the laying period. We measured egg mass, length, and width once and only during the first three days of incubation to control for water loss during embryonic development. We measured egg mass with an Acculab Pocketpro (Arvada, Colorado) scale $( \pm 0.001 \mathrm{~g})$, and measured egg length and width with digital calipers (Mitotoyu Corp., Japan; $\pm 0.01 \mathrm{~mm}$ ). A small fraction of nests were depredated or otherwise failed before the completion of the clutch and these nests were not included in analyses of clutch size, egg mass, or egg size. 
We measured adult mass and tarsus length when individuals were captured and banded with unique color-band combinations as part of a concurrent study of adult survival (Ghalambor and Martin 2001, Martin 2002). We measured adult body mass with Pesola (Baar, Switzerland) spring scales $( \pm 0.25-0.5 \mathrm{~g})$. Tarsus length was measured with Mitotoyu digital calipers $( \pm 0.01 \mathrm{~mm})$ as the distance from the tibiotarsus joint to the far end of the last leg scale where the toes emerge. We sexed individual birds in the hand using sex-specific plumage characteristics or by the presence or absence of a brood patch or cloacal protuberance. Only three species (Slaty Thrush, Rufousbellied Thrush, and Masked Yellowthroat) were dichromatic, such that a brood patch or cloacal protuberance was the primary means of sex determination for most species.

We calculated developmental period lengths based on observed transition events such as clutch completion, hatching, and fledging. We defined incubation period length as the number of days from the day the last egg in the clutch was laid to the day the last egg hatched, and the nestling period as the number of days from when the last egg in the clutch hatched to when the last nestling fledged. We included in the analysis of developmental period length only those nests whose stage transitions could be precisely determined through observations on two consecutive days.

\section{PARENTAL CARE}

We used video cameras to record parental care at the nest during the incubation and nestling periods (Martin and Ghalambor 1999). We videotaped nests once on a randomly chosen day during the incubation period; analyses indicate that nest attentiveness does not change across the incubation period (TEM, unpubl. data). During the nestling period, we filmed nests within one day of the primary pin feathers breaking their sheaths to control for variation in nestling developmental rates across species. Cameras were set up within one-half hour of sunrise, and we sought to tape each nest for six continuous hours. However, due to various factors (e.g., batteries dying), taping varied from 4 to $8 \mathrm{hr}$ per nest. We set up cameras when the parent had left the nest of its own accord to minimize disturbance. Cameras were camouflaged and set up either on tripods, on fallen $\operatorname{logs}$, or on other substrates and at a distance that minimized parental disturbance.

Videotapes were brought back to the laboratory at the University of Montana and scored to measure nest attentiveness during the incubation period and the rate at which adults fed nestlings during the nestling period (Martin et al. 2000, Martin 2002). We calculated nest attentiveness as the percentage of time that parents spent on the nest over the total time of the video. Nestling feeding rates were calculated as the number of trips parents made to the nest with food over the total time of the video, and are presented as an hourly rate. Only those videos in which we could confirm that parents were sitting on the nest or were delivering food to nestlings were used in the analyses. We did not include data from rare videos that showed parents exhibiting unusual behavior, for example not returning to the nest or calling near the nest, in this analysis or in the estimation of mortality rates. We noted parental care roles of males and females both through direct observation during nest searching and checking and through video observation. When possible, we sexed adults on the videotapes by plumage differences or by unique colored leg bands of individuals whose sex was previously determined from the concurrent banding study (see Nesting Biology, above).

\section{STATISTICAL ANALYSES}

We pooled data across all three years for all analyses because sample sizes for many breeding parameters were too small to yield significant statistical power in tests and because we were interested in providing generalized estimates for species. We compared Mayfield estimates of daily nest mortality and predation rates across species using chi-square analysis with program CONTRAST (Hines and Sauer 1989). We compared reproductive traits across species and nest types with a one-way ANOVA and least significant difference (LSD) post-hoc tests. We examined correlations of traits with mean daily predation rates or body mass using Pearson's correlations. The latter two analyses were done using SPSS version 12.0 (SPSS 2003). All values reported are means $\pm \mathrm{SE}$.

\section{RESULTS}

We located and monitored a total of 1716 nests, of which 1189 (341 in 1997, 512 in 1998, and 
TABLE 1. Types and heights of nests of 18 forest passerines at El Rey National Park, Argentina, $1997-1999$.

\begin{tabular}{lccc}
\hline \hline & & \multicolumn{1}{c}{ Nest height (m) } \\
\cline { 3 - 4 } \multicolumn{1}{c}{ Species } & Nest type & Mean \pm SE (n) & Range \\
\cline { 3 - 4 } Buff-browed Foliage-gleaner (Syndactyla rufosuperciliata) & Cavity & $6.9 \pm 1.3(11)$ & $1.0-15.0$ \\
Small-billed Elaenia (Elaenia parvirostris) & Open-cup & $5.0 \pm 0.9(14)$ & $1.0-12.0$ \\
Slaty Elaenia (Elaenia strepera) & Open-cup & $11.3 \pm 1.3(17)$ & $1.7-21.2$ \\
Mottle-cheeked Tyrannulet (Phylloscartes ventralis) & Enclosed & $4.5 \pm 0.5(84)$ & $0.3-20.0$ \\
Ochre-faced Tody-Flycatcher (Poecilotriccus plumbeiceps) & Enclosed & $1.8 \pm 0.1(19)$ & $1.0-3.0$ \\
Euler's Flycatcher (Lathrotriccus euleri) & Open-cup & $4.0 \pm 0.6(42)$ & $0.7-18.4$ \\
House Wren (Troglodytes aedon) & Cavity & $4.3 \pm 1.0(18)$ & $1.0-17.0$ \\
Mountain Wren (Troglodytes solstitialis) & Cavity & $12.1 \pm 1.6(15)$ & $2.0-20.0$ \\
Spotted Nightingale-Thrush (Catharus dryas) & Open-cup & $1.4 \pm 0.1(39)$ & $0.7-3.9$ \\
Slaty Thrush (Turdus nigriceps) & Open-cup & $3.6 \pm 0.4(95)$ & $0.0-20.3$ \\
Rufous-bellied Thrush (Turdus rufiventris) & Open-cup & $4.5 \pm 0.4(106)$ & $0.0-22.5$ \\
Rufous-collared Sparrow (Zonotrichia capensis) & Open-cup & $0.4 \pm 0.1(15)$ & $0.0-1.9$ \\
Saffron-billed Sparrow (Arremon flavirostris) & Enclosed & $0.0 \pm 0.0(54)$ & $0.0-0.9$ \\
Stripe-headed Brush-Finch (Buarremon torquatus) & Open-cup & $1.8 \pm 0.1(131)$ & $2.0-8.3$ \\
Masked Yellowthroat (Geothlypis aequinoctalis) & Open-cup & $0.2 \pm 0.1(12)$ & $0.0-0.5$ \\
Brown-capped Redstart (Myioborus brunniceps) & Enclosed & $0.0 \pm 0.0(33)$ & 0.0 \\
Two-banded Warbler (Basileuterus bivittatus) & Enclosed & $0.0 \pm 0.0(83)$ & 0.0 \\
Pale-legged Warbler (Basileuterus signatus) & Enclosed & $0.0 \pm 0.0(34)$ & 0.0 \\
\hline
\end{tabular}

336 in 1999) belonged to the 18 most common species summarized here.

\section{NEST TYPES AND HEIGHTS}

The 18 common species constructed three main nest types that differed in structure and height (Table 1). Fifty percent of the species constructed open-cup nests, 33\% built enclosed nests, and the remaining $17 \%$ nested in tree cavities (Table 1). Mean nest heights ranged from 0.0 to $12.1 \mathrm{~m}$ across species, but also varied considerably within species that nested off the ground (Table 1).

\section{NEST SUCCESS AND PREDATION}

Daily mortality rates due to all causes differed across species for the incubation period $\left(\chi^{2}{ }_{16}=\right.$ 61.2, $P<0.001)$, the nestling period $\left(\chi_{16}^{2}=\right.$ 91.6, $P<0.001)$, and the overall nesting period $\left(\chi^{2}{ }_{17}=108.7, P<0.001\right)$. Daily nest predation rates also differed across species for the incubation period $\left(\chi_{16}^{2}=77.7, P<0.001\right)$, the nestling period $\left(\chi_{16}^{2}=94.9, P<0.001\right)$, and the overall nesting period $\left(\chi_{17}^{2}=122.2, P<0.001\right.$; Table 2). Nest predation was the primary cause of nest failure, accounting for $86 \%$ of all failures, while the remaining nest failures were due to weather, primarily heavy rains, or abandonment. Daily nest predation rates differed among nest types during both the incubation $\left(F_{2,14}=14.7, P<0.001\right)$ and nestling $\left(F_{2,14}=8.8, P=0.003\right)$ stages. During the incubation period, open-cup nests had the highest predation rates (vs. enclosed: $P<$ 0.001 LSD; vs. cavity: $P=0.007$ LSD), followed by enclosed and cavity nests (enclosed vs. cavity: $P=0.80 \mathrm{LSD}$; Table 3 ). During the nestling period, open-cup and enclosed nest predation rates did not differ $(P=0.26 \mathrm{LSD})$, but both were significantly higher than those experienced by cavity nests (cavity vs. opencup: $P=0.001$ LSD; cavity vs. enclosed: $P=$ 0.006 LSD). When all nesting stages were combined, predation rates differed among nest types $\left(F_{2,15}=26.0, P<0.001\right)$. Open-cup nests had significantly higher overall predation rates than enclosed $(P<0.001)$ and cavity nests $(P<$ $0.001)$. Enclosed nests had higher overall predation rates than cavity nests $(P=0.02$ LSD). Field researchers and video footage identified a diversity of nest predators including: Squirrel Cuckoo (Piaya cayana), Toco Toucan (Ramphastos toco), Plush-crested Jay (Cyanocorax chrysops), Tayra (Eira barbara), an unidentified fox species, and several unidentified snake species.

\section{NESTING BIOLOGY}

Mean initiation dates for first nests differed significantly among species $\left(F_{16,91}=34.9, P<\right.$ 0.001 ), but generally first nests were initiated in mid to late October (Fig. 1). Mean initiation dates for first nests also differed among nest types $\left(F_{2,13}=4.2, P=0.03\right)$. Enclosed nests 
TABLE 2. Mayfield estimates of daily nest predation rates of 18 passerines at El Rey National Park, Argentina, 1997-1999. Mayfield estimates are calculated as the number of depredated nests divided by the total (exposure) days all nests were observed. Exposure days are summed over the incubation and nestling periods. Sample size $(n)=$ number of nests in the overall nesting period. Daily predation rates for incubation and nestling periods were calculated only for those species with $\geq 20$ nests active during each respective period. Overall nesting period daily predation rates are for the combined incubation and nestling periods.

\begin{tabular}{|c|c|c|c|c|}
\hline \multirow[b]{2}{*}{ Species } & \multirow{2}{*}{$\begin{array}{l}\text { Exposure } \\
\text { days }(n)\end{array}$} & \multicolumn{3}{|c|}{ Daily predation rate $\pm \mathrm{SE}$} \\
\hline & & Incubation period & Nestling period & Overall nesting period \\
\hline Buff-browed Foliage-gleaner & $583(43)$ & $0.013 \pm 0.007$ & $0.006 \pm 0.004$ & $0.009 \pm 0.004$ \\
\hline Small-billed Elaenia & $356(45)$ & $0.055 \pm 0.015$ & $0.031 \pm 0.017$ & $0.048 \pm 0.011$ \\
\hline Slaty Elaenia & $223(26)$ & $0.038 \pm 0.015$ & $0.053 \pm 0.030$ & $0.040 \pm 0.013$ \\
\hline Mottle-cheeked Tyrannulet & $1819(133)$ & $0.018 \pm 0.005$ & $0.035 \pm 0.006$ & $0.026 \pm 0.004$ \\
\hline Ochre-faced Tody-Flycatcher & $507(23)$ & $0.010 \pm 0.006$ & $0.026 \pm 0.012$ & $0.016 \pm 0.006$ \\
\hline Euler's Flycatcher & $696(59)$ & $0.026 \pm 0.009$ & $0.039 \pm 0.011$ & $0.032 \pm 0.007$ \\
\hline House Wren & $510(40)$ & $0.019 \pm 0.010$ & $0.004 \pm 0.004$ & $0.012 \pm 0.005$ \\
\hline Mountain Wren & $287(23)$ & - & - & $0.004 \pm 0.004$ \\
\hline Spotted Nightingale-Thrush & $665(59)$ & $0.039 \pm 0.010$ & $0.049 \pm 0.013$ & $0.044 \pm 0.008$ \\
\hline Slaty Thrush & $1240(132)$ & $0.054 \pm 0.009$ & $0.064 \pm 0.011$ & $0.057 \pm 0.007$ \\
\hline Rufous-bellied Thrush & $1553(146)$ & $0.045 \pm 0.007$ & $0.064 \pm 0.010$ & $0.052 \pm 0.006$ \\
\hline Rufous-collared Sparrow & $344(30)$ & $0.069 \pm 0.019$ & $0.033 \pm 0.015$ & $0.050 \pm 0.012$ \\
\hline Saffron-billed Sparrow & $1066(81)$ & $0.018 \pm 0.005$ & $0.037 \pm 0.009$ & $0.026 \pm 0.005$ \\
\hline Stripe-headed Brush-Finch & $1953(161)$ & $0.048 \pm 0.006$ & $0.033 \pm 0.007$ & $0.042 \pm 0.005$ \\
\hline Masked Yellowthroat & $467(56)$ & $0.023 \pm 0.009$ & $0.031 \pm 0.015$ & $0.026 \pm 0.007$ \\
\hline Brown-capped Redstart & $528(39)$ & $0.012 \pm 0.007$ & $0.036 \pm 0.012$ & $0.023 \pm 0.007$ \\
\hline Two-banded Warbler & $1442(113)$ & $0.009 \pm 0.004$ & $0.031 \pm 0.007$ & $0.020 \pm 0.004$ \\
\hline Pale-legged Warbler & $555(38)$ & $0.016 \pm 0.007$ & $0.055 \pm 0.015$ & $0.031 \pm 0.007$ \\
\hline
\end{tabular}

were initiated earlier than open-cup nests $(P=$ 0.01 LSD), but initiation dates of cavity versus open-cup nests ( $P=0.20$ LSD) and cavity versus enclosed nests $(P=0.50 \mathrm{LSD})$ did not differ (Table 3). The mean breeding season duration was $49.8 \pm 3.9$ days, but varied substantially among species (Table 4). Variation in season length across species was not associated with variation in clutch size $(r=$ $-0.31, P=0.23)$.

Mean clutch size across 18 species was $2.7 \pm$ 0.1 and ranged from 2.0 to 3.5 mean eggs per clutch (Table 5). Clutch size also differed among nest types $\left(F_{2,14}=9.0, P=0.003\right.$; Table 3). Cavity nests had significantly larger clutch sizes than both enclosed nests $(P=0.01$

TABLE 3. Mean breeding parameters across nest types of 18 forest passerines at El Rey National Park, Argentina, 1997-1999. All means represent the mean of average species values. Mean clutch size was calculated as the final number of eggs observed on two consecutive nest visits immediately following the end of laying. Incubation and nestling periods were calculated as the mean number of days observed for the stage; only nests wherein transitions between stages could be identified exactly by checking nest contents on consecutive days were used ( $n=210$ for the incubation period, $n=207$ nests for the nestling period). Overall daily predation rates were calculated following Mayfield (1961, 1965) and variance estimates following Hensler and Nichols (1981). Nest attentiveness is the percentage of daylight hours both adults combined spent on the nest. Nestling feeding rates are the mean number of feeding trips to the nest per hr. Data for incubation nest attentiveness and nestling feeding rates were obtained using video cameras, and only nests with at least $4 \mathrm{hr}$ of footage were used for estimates ( $n=204$ nests for nest attentiveness, $n=164$ nests for nestling feeding rate).

\begin{tabular}{lccccccc}
\hline \hline & \multicolumn{6}{c}{ Mean parameter \pm SE } \\
\cline { 2 - 8 } Nest type & $\begin{array}{c}\text { Date of } \\
\text { first nest }\end{array}$ & $\begin{array}{c}\text { Clutch } \\
\text { size }\end{array}$ & $\begin{array}{c}\text { Incubation } \\
\text { period length } \\
\text { (days) }\end{array}$ & $\begin{array}{c}\text { Nestling } \\
\text { period } \\
\text { length (days) }\end{array}$ & $\begin{array}{c}\text { Overall daily } \\
\text { predation } \\
\text { rate }\end{array}$ & $\begin{array}{c}\text { Incubation nest } \\
\text { attentiveness } \\
(\%)\end{array}$ & $\begin{array}{c}\text { Hourly } \\
\text { nestling } \\
\text { feeding rate }\end{array}$ \\
\hline Open cup & 29 October & $2.4 \pm 0.1$ & $14.6 \pm 1.0$ & $14.1 \pm 1.0$ & $0.043 \pm 0.003$ & $66 \pm 2$ & $9.3 \pm 2.2$ \\
Enclosed & 13 October & $2.7 \pm 0.1$ & $16.7 \pm 0.6$ & $13.9 \pm 1.2$ & $0.024 \pm 0.002$ & $60 \pm 3$ & $11.5 \pm 1.9$ \\
Cavity & 19 October & $3.5 \pm 0.0$ & $16.1 \pm 1.3$ & $17.9 \pm 1.6$ & $0.008 \pm 0.004$ & $75 \pm 12$ & $14.8 \pm 0.8$ \\
\hline
\end{tabular}



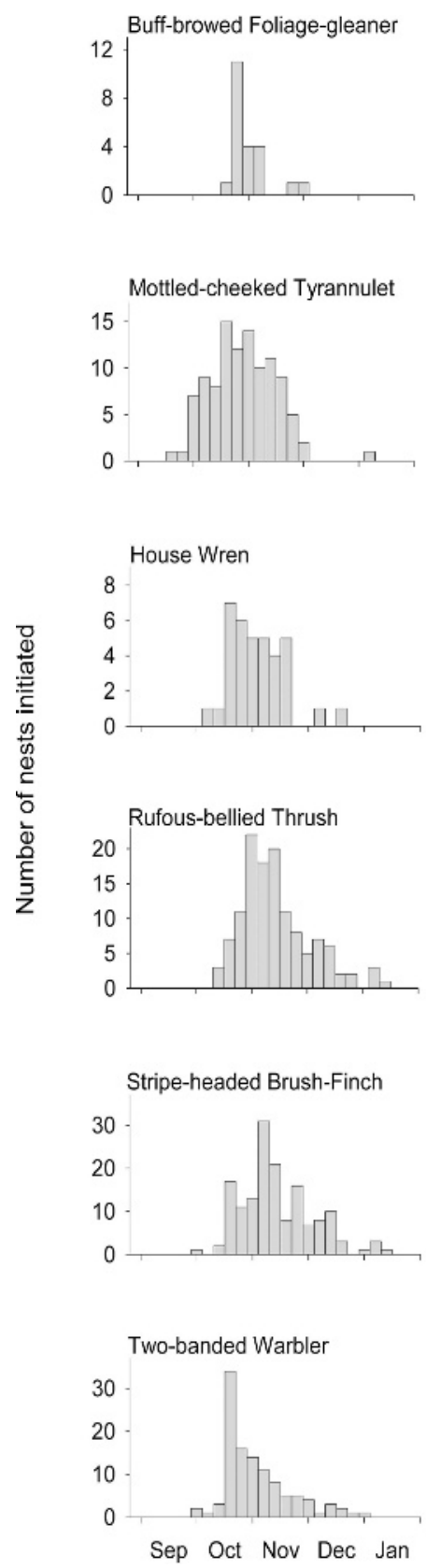
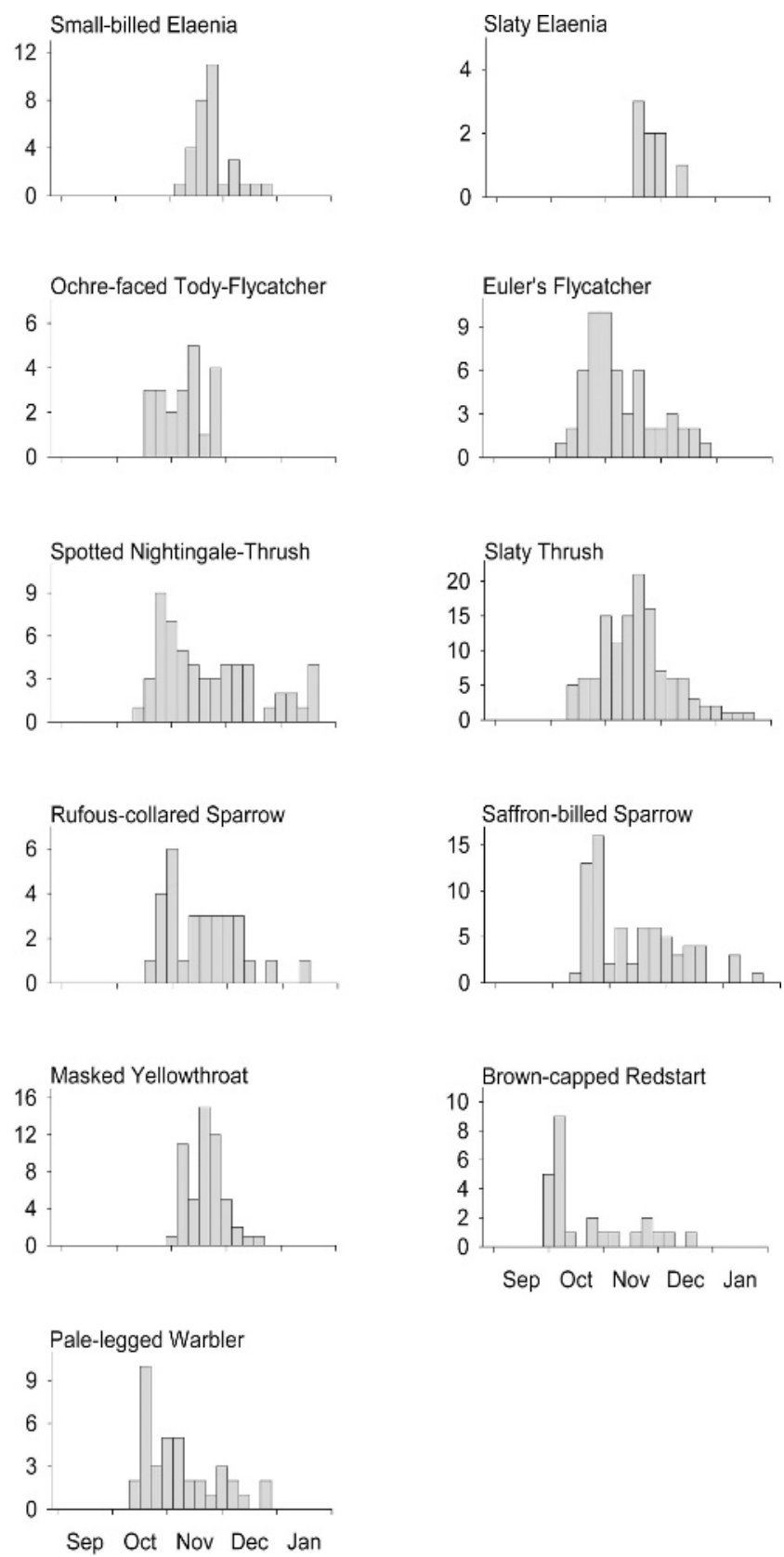

FIGURE 1. Distribution of nest initiation dates of forest passerines at El Rey National Park, Argentina, 1997-1999. Bars represent number of nests initiated in seven-day intervals within each month. Some intervals overlap the transition between months. Note the different frequencies on the $y$-axes.

LSD) and open-cup nests ( $P=0.001 \mathrm{LSD})$, but $\quad-0.61, P=0.006)$ and with incubation preclutch size did not differ between open-cup and dation rate $(r=-0.50, P=0.04)$. Mean egg enclosed nests $(P=0.12 \mathrm{LSD})$. Across species, mass varied among species (Table 6), was log-transformed clutch size was negatively positively correlated with adult body mass $(r$ correlated with overall predation rate $(r==0.96, P<0.001$; Table 7), and negatively 
TABLE 4. Breeding season initiation dates and duration for 18 forest passerines at El Rey National Park, Argentina, 1997-1999. Sample size $(n)=$ number of nests. Mean breeding initiation date is the mean date that the first egg was laid in the first $10 \%$ of nests of the season. Duration of the breeding season was measured as the difference between the earliest and latest date of the middle $90 \%$ of nest initiation dates.

\begin{tabular}{lrcc}
\hline \hline \multicolumn{1}{c}{ Species } & $n$ & $\begin{array}{l}\text { Mean breeding } \\
\text { initiation date }\end{array}$ & $\begin{array}{c}\text { Duration of breeding } \\
\text { season (days) }\end{array}$ \\
\hline Buff-browed Foliage-gleaner & 22 & 25 October & 30.1 \\
Small-billed Elaenia & 31 & 13 November & 32.9 \\
Slaty Elaenia & 8 & 18 November & 28.0 \\
Mottle-cheeked Tyrannulet & 105 & 3 October & 51.1 \\
Ochre-faced Tody-Flycatcher & 21 & 23 October & 32.2 \\
Euler's Flycatcher & 56 & 17 October & 56.7 \\
House Wren & 36 & 15 October & 35.0 \\
Spotted Nightingale-Thrush & 58 & 23 October & 84.7 \\
Slaty Thrush & 124 & 20 October & 65.1 \\
Rufous-bellied Thrush & 128 & 21 October & 63.7 \\
Rufous-collared Sparrow & 30 & 26 October & 44.1 \\
Saffron-billed Sparrow & 72 & 21 October & 60.2 \\
Stripe-headed Brush-Finch & 154 & 19 October & 62.3 \\
Masked Yellowthroat & 53 & 6 November & 30.1 \\
Brown-capped Redstart & 38 & 5 October & 58.8 \\
Two-banded Warbler & 111 & 14 October & 55.3 \\
Pale-legged Warbler & 38 & 19 October & 56.7 \\
\hline
\end{tabular}

correlated with clutch size after controlling for body mass $(r=-0.68, P=0.04)$.

Across species, mean incubation and nestling periods ranged from 12.5 to 19.0 and 9.7 to 20.0 days, respectively (Table 5). Mean incubation period did not differ statistically among nest types $\left(F_{2,14}=2.9, P=0.09\right.$; Table 3$)$, but tended to be shorter in open-cup nesters than enclosed and cavity-nesters. Nestling periods did not differ across nest types $\left(F_{2,14}=2.4, P=\right.$ 0.14 ; Table 3 ) nor did overall nesting period length (incubation and nestling combined; $F_{2,13}$

TABLE 5. Mean clutch size and nesting period lengths of 18 forest passerines at El Rey National Park, Argentina, 1997-1999. Mean clutch size was calculated as the final number of eggs observed on two consecutive nest visits immediately following the end of laying. Incubation and nestling periods were calculated as the mean number of days observed for the stage; only nests wherein transitions between stages could be identified exactly by checking nest contents on consecutive days were used. Sample size $(n)=$ number of nests.

\begin{tabular}{lccl}
\hline \hline \multicolumn{1}{c}{ Species } & $\begin{array}{c}\text { Mean clutch } \\
\text { size } \pm \text { SE }(n)\end{array}$ & $\begin{array}{c}\text { Mean incubation } \\
\text { period } \pm \text { SE }(n)\end{array}$ & $\begin{array}{c}\text { Mean nestling } \\
\text { period } \pm \text { SE }(n)\end{array}$ \\
\hline Buff-browed Foliage-gleaner & $3.5 \pm 0.2(6)$ & $18.6 \pm 0.4(5)$ & $20.0 \pm 2.0(2)$ \\
Small-billed Elaenia & $2.0(1)$ & $14.8 \pm 0.3(5)$ & $19.3 \pm 0.3(3)$ \\
Slaty Elaenia & $2.0(1)$ & $15.5 \pm 1.4(3)$ & - \\
Mottle-cheeked Tyrannulet & $2.8 \pm 0.1(20)$ & $17.8 \pm 0.1(21)$ & $17.1 \pm 0.5(16)$ \\
Ochre-faced Tody-Flycatcher & $2.6 \pm 0.2(9)$ & $19.0 \pm 0.3(13)$ & $18.3 \pm 0.4(6)$ \\
Euler's Flycatcher & $2.6 \pm 0.1(17)$ & $17.1 \pm 0.7(8)$ & $15.2 \pm 0.2(12)$ \\
House Wren & $3.5 \pm 0.3(8)$ & $15.8 \pm 0.2(6)$ & $14.8 \pm 0.3(9)$ \\
Mountain Wren & $2.0 \pm 0.0(11)$ & $14.4 \pm 0.4(6)$ & $18.8 \pm 1.3(2)$ \\
Spotted Nightingale-Thrush & $2.8 \pm 0.1(25)$ & $12.5 \pm 0.3(18)$ & $14.4 \pm 0.3(7)$ \\
Slaty Thrush & $2.7 \pm 0.1(28)$ & $13.1 \pm 0.1(32)$ & $13.0 \pm 0.3(14)$ \\
Rufous-bellied Thrush & $2.6 \pm 0.2(8)$ & $14.4 \pm 0.4(20)$ \\
Rufous-collared Sparrow & $2.8 \pm 0.1(23)$ & $15.3 \pm 0.3(16)$ & $14.0 \pm 0.6(5)$ \\
Saffron-billed Sparrow & $2.1 \pm 0.6(38)$ & $15.8 \pm 0.2(24)$ & $12.2 \pm 0.2(19)$ \\
Stripe-headed Brush-Finch & $3.1 \pm 0.1(11)$ & $13.3 \pm 0.4(4)$ & $12.8 \pm 0.2(30)$ \\
Masked Yellowthroat & $2.6 \pm 0.1(15)$ & $16.6 \pm 0.6(5)$ & $9.7 \pm 0.3(5)$ \\
Brown-capped Redstart & $2.9 \pm 0.1(36)$ & $14.8 \pm 0.1(31)$ & $12.6 \pm 0.5(11)$ \\
Two-banded Warbler & $2.6 \pm 0.1(19)$ & $16.6 \pm 0.3(12)$ & $10.9 \pm 0.2(37)$ \\
Pale-legged Warbler & & & $12.5 \pm 0.3(9)$ \\
\hline
\end{tabular}


TABLE 6. Mean egg sizes of a sample of forest passerines at El Rey National Park, Argentina, 1997-1999. All eggs of each nest were measured within three days of clutch completion to minimize potential bias due to water loss. Sample size $(n)=$ number of nests in which eggs were measured.

\begin{tabular}{lcccc}
\hline \hline \multirow{2}{*}{\multicolumn{1}{c}{ Species }} & \multicolumn{3}{c}{ Mean egg sizes \pm SE } \\
\cline { 2 - 5 } \multicolumn{1}{c}{ Egg mass (g) } & Egg length (mm) & Egg width (mm) & $n$ \\
\hline Mottle-cheeked Tyrannulet & $1.37 \pm 0.07$ & $17.0 \pm 0.1$ & $12.9 \pm 0.2$ & 2 \\
Ochre-faced Tody-Flycatcher & $1.15 \pm 0.01$ & $16.9 \pm 0.1$ & $11.8 \pm 0.1$ & 2 \\
Euler's Flycatcher & $1.69 \pm 0.02$ & $17.8 \pm 0.3$ & $13.6 \pm 0.1$ & 2 \\
House Wren & $1.41 \pm 0.01$ & $17.0 \pm 0.1$ & $13.4 \pm 0.1$ & 4 \\
Spotted Nightingale-Thrush & $4.53 \pm 0.20$ & $25.4 \pm 0.4$ & $18.9 \pm 0.3$ & 10 \\
Slaty Thrush & $5.26 \pm 0.16$ & $26.9 \pm 0.3$ & $19.6 \pm 0.2$ & 13 \\
Rufous-bellied Thrush & $5.77 \pm 0.08$ & $27.7 \pm 0.5$ & $20.0 \pm 0.1$ & 9 \\
Rufous-collared Sparrow & $2.69 \pm 0.08$ & $20.5 \pm 0.2$ & $15.9 \pm 0.1$ & 6 \\
Saffron-billed Sparrow & $2.90 \pm 0.14$ & $22.3 \pm 0.5$ & $15.8 \pm 0.2$ & 4 \\
Stripe-headed Brush-Finch & $3.77 \pm 0.10$ & $24.3 \pm 0.3$ & $16.7 \pm 0.1$ & 18 \\
Masked Yellowthroat & $1.93 \pm 0.04$ & $18.4 \pm 0.2$ & $14.1 \pm 0.1$ & 12 \\
Brown-capped Redstart & $1.59 \pm 0.08$ & $17.3 \pm 0.4$ & $13.4 \pm 0.1$ & 6 \\
Two-banded Warbler & $2.31 \pm 0.05$ & $21.0 \pm 0.4$ & $14.5 \pm 0.1$ & 7 \\
Pale-legged Warbler & $2.23 \pm 0.03$ & $19.5 \pm 0.2$ & $14.8 \pm 0.2$ & 7 \\
\hline
\end{tabular}

$=1.9, P=0.20)$. Incubation period length was negatively related to incubation nest predation rate $(r=-0.62, P=0.01)$, but nestling period length was not correlated with nestling predation rate $(r=-0.37, P=0.16)$ nor was overall period length related to overall predation rate $(r=-0.42, P=0.11)$.

\section{PARENTAL CARE}

Only females incubated the eggs in all but one species, the Buff-browed Foliage-gleaner (a furnariid), in which both sexes incubated. Incubation feeding, where males fed incubating females on the nest, was observed in nine species (Table 8). Both adults participated in feeding nestlings in all species (Table 8).

Nest attentiveness ranged from $52 \%$ to $98 \%$, with all but three species exhibiting attentiveness less than 70\% (Table 8). Nest attentiveness did not differ across nest types $\left(F_{2,15}=2.4, P=\right.$ 0.13 ; Table 3). Differences in nest attentiveness among species with female-only incubation were not related to the presence or absence of incubation feeding $\left(F_{1,16}=1.0, P=0.33\right)$.

Mean nestling feeding rates ranged from 4.9 to 21.5 trips $\mathrm{hr}^{-1}$ across species and did not differ among nest types $\left(F_{2,13}=1.4, P=0.29\right.$; Table 3). Mean feeding rates were positively

TABLE 7. Mean adult body mass and tarsus length of a sample of forest passerines at El Rey National Park, Argentina, 1997-1999. Body mass and tarsus length were measured as part of a mark-recapture study of adult survival. Body mass was measured as the total mass of the live bird using Pesola spring scales and tarsus length was measured with digital calipers as the distance from the tibiotarsus joint to the far end of the last leg scale where the toes emerge.

\begin{tabular}{|c|c|c|c|c|}
\hline \multirow[b]{2}{*}{ Species } & \multicolumn{2}{|c|}{ Mean adult body mass $(\mathrm{g}) \pm \mathrm{SE}(n)$} & \multicolumn{2}{|c|}{ Mean adult tarsus length $(\mathrm{mm}) \pm \mathrm{SE}(n)$} \\
\hline & Male & Female & Male & Female \\
\hline Euler's Flycatcher & $10.8 \pm 0.3(2)$ & $10.0(1)$ & $14.8 \pm 0.4(2)$ & $15.0(1)$ \\
\hline Spotted Nightingale-Thrush & $40.3 \pm 6.9(3)$ & $33.5 \pm 0.5(4)$ & $32.7 \pm 1.7(3)$ & $32.9 \pm 0.4(3)$ \\
\hline Slaty Thrush & $53.7 \pm 2.3(5)$ & $58.0 \pm 4.0(2)$ & $30.5 \pm 0.4(5)$ & $31.3 \pm 2.2(2)$ \\
\hline Rufous-bellied Thrush & $59.2 \pm 0.9(7)$ & $64.0 \pm 1.7(3)$ & $34.9 \pm 0.4(7)$ & $34.1 \pm 0.6(4)$ \\
\hline Saffron-billed Sparrow & $25.1 \pm 0.8(5)$ & $23.6 \pm 0.4(7)$ & $24.0 \pm 0.3(6)$ & $24.3 \pm 0.2(7)$ \\
\hline Stripe-headed Brush-Finch & $33.3 \pm 0.7(6)$ & $34.0 \pm 0.8(4)$ & $27.1 \pm 0.4(5)$ & $27.4 \pm 0.2(6)$ \\
\hline Masked Yellowthroat & $12.8(1)$ & - 17.0 (ד) & $21.4(1)$ & $21.7-0.2(0)$ \\
\hline Brown-capped Redstart & $8.9 \pm 0.2(3)$ & $8.8 \pm 0.3(4)$ & $19.3 \pm 0.2(3)$ & $18.9 \pm 0.5(4)$ \\
\hline Two-banded Warbler & $14.2 \pm 0.4(20)$ & $14.0 \pm 0.3(14)$ & $23.3 \pm 0.2(20)$ & $23.3 \pm 0.4(12)$ \\
\hline Pale-legged Warbler & $12.0 \pm 0.3(9)$ & $11.8 \pm 0.6(4)$ & $24.0 \pm 0.3(10)$ & $22.4 \pm 0.3(5)$ \\
\hline
\end{tabular}


TABLE 8. Parental care by males (M) and females (F) during the incubation and nestling period of 18 forest passerines at El Rey National Park, Argentina, 1997-1999. Nest attentiveness is the mean percentage time spent on the nest and was measured using video cameras over a 4-8 hr period during the morning to early afternoon. Nests were taped during a randomly chosen day during the incubation period. "Inc feed" refers to the presence of incubation feeding (i.e., the feeding of females on the nest by their mates). Nestling feeding rates are the mean number of trips per hour adults made to the nest with food that was fed to nestlings on the day the nestlings' primary pin feathers broke their sheaths. Estimates include both male and female contributions. Data was obtained using video cameras and only nests with at least $4 \mathrm{hr}$ of footage were used for estimates.

\begin{tabular}{|c|c|c|c|c|c|}
\hline \multirow[b]{2}{*}{ Species } & \multicolumn{4}{|c|}{ Incubation } & \multirow{2}{*}{$\begin{array}{c}\text { Nestling } \\
\text { Mean feeding } \\
\text { rates } \pm \mathrm{SE}(n)\end{array}$} \\
\hline & Inc & $\begin{array}{c}\text { Mean nest } \\
\text { attentiveness } \pm \text { SE }(n)\end{array}$ & $\begin{array}{l}\text { Inc } \\
\text { feed }\end{array}$ & $\begin{array}{c}\text { Feed } \\
\text { nestlings }\end{array}$ & \\
\hline Buff-browed Foliage-gleaner & MF & $98.4 \pm 1.5(2)$ & No & MF & $16.2 \pm 2.0(10)$ \\
\hline Small-billed Elaenia & $\mathrm{F}$ & $76.2 \pm 2.4(7)$ & Unknown & MF & - \\
\hline Slaty Elaenia & $\mathrm{F}$ & $66.8(1)$ & Unknown & MF & - \\
\hline Mottle-cheeked Tyrannulet & $\mathrm{F}$ & $53.2 \pm 2.2(13)$ & Unknown & MF & $15.4 \pm 1.8(11)$ \\
\hline Ochre-faced Tody-Flycatcher & $\mathrm{F}$ & $52.4 \pm 2.4(12)$ & Unknown & MF & $18.4 \pm 0.7(4)$ \\
\hline Euler's Flycatcher & $\mathrm{F}$ & $64.2 \pm 2.3(19)$ & Yes & MF & $21.5 \pm 2.8(12)$ \\
\hline House Wren & $\mathrm{F}$ & $64.9 \pm 4.7(5)$ & Yes & MF & $14.7 \pm 0.8(6)$ \\
\hline Mountain Wren & $\mathrm{F}$ & $60.6(1)$ & Yes & MF & $13.6 \pm 1.8(4)$ \\
\hline Spotted Nightingale-Thrush & $\mathrm{F}$ & $67.1 \pm 2.1(17)$ & Yes & MF & $5.6 \pm 0.4(13)$ \\
\hline Slaty Thrush & $\mathrm{F}$ & $66.2 \pm 1.8(16)$ & Unknown & MF & $10.2 \pm 1.2(13)$ \\
\hline Rufous-bellied Thrush & $\mathrm{F}$ & $71.0 \pm 2.4(14)$ & Unknown & $\mathrm{MF}$ & $9.0 \pm 0.9(10)$ \\
\hline Rufous-collared Sparrow & $\mathrm{F}$ & $66.0 \pm 6.9(4)$ & Unknown & MF & $5.8 \pm 2.2(2)$ \\
\hline Saffron-billed Sparrow & $\mathrm{F}$ & $61.8 \pm 3.1(24)$ & Yes & MF & $4.9 \pm 0.3(19)$ \\
\hline Stripe-headed Brush-Finch & $\mathrm{F}$ & $54.9 \pm 3.1(19)$ & Yes & $\mathrm{MF}$ & $5.0 \pm 0.4(15)$ \\
\hline Masked Yellowthroat & $\mathrm{F}$ & $61.0 \pm 4.2(6)$ & Unknown & MF & $7.9 \pm 0.8(7)$ \\
\hline Brown-capped Redstart & $\mathrm{F}$ & $67.4 \pm 5.0(6)$ & Yes & MF & $10.2 \pm 2.1(9)$ \\
\hline Two-banded Warbler & $\mathrm{F}$ & $62.3 \pm 2.3(22)$ & Yes & MF & $9.2 \pm 0.5(19)$ \\
\hline Pale-legged Warbler & $\mathrm{F}$ & $64.6 \pm 2.0(16)$ & Yes & MF & $11.1 \pm 1.1(10)$ \\
\hline
\end{tabular}

correlated with nestling period length $(r=0.64$, $P=0.007)$ and negatively correlated with overall predation rate $(r=-0.50, P=0.05)$.

\section{DISCUSSION}

The 18 coexisting study species exhibited a range of variation in all reproductive traits measured. Environmental selection pressures such as nest predation also differed among species and explained some of the interspecific variation in breeding traits.

Nests varied in height within and among nest types and were found in all vegetation layers of the forest, including the ground, understory, subcanopy, and canopy layers. One of the biggest differences between species in this subtropical community compared to north temperate zones was the greater prevalence of enclosed nests. The prevalence of enclosed nests has been observed in other tropical and south temperate communities (Collias and Collias 1984) and raises the interesting question of why enclosed nests are more common in the south.
Nest design and placement may evolve in response to nest failure due to ecological factors such as weather or nest predation, and the diversity of nest types and placement may represent different strategies for minimizing such failures (Snow 1978, Collias and Collias 1984). The nesting season in many tropical and southern sites corresponds with the rainy season, and exposure to rain can lead to nest failure. Species may reduce rain-imposed costs by constructing nests with materials that dry out quickly, by building enclosed nests with a roof that shields the contents, or by placing nests in sheltered sites (Snow 1978, Collias and Collias 1984, Slagsvold 1989).

On the other hand, nest predation was the primary cause of nesting mortality at our site, which is consistent with studies in both tropical and north temperate areas (Ricklefs 1969, Martin 1995). Nest predation levels were similar to those reported for north temperate as well as high elevation tropical sites (Oniki 1979, Skutch 1985, Martin 1995, Martin et al. 2006), but lower than those reported for many low elevation 
tropical and southern hemisphere sites (Skutch 1949, Kulesza 1990, Major 1991). Nest predation may exert strong selection pressures on nest design and placement (Collias and Collias 1984, Martin 1988). Cavity nests generally suffer lower predation than open-cup nests (Martin 1995). Enclosed nests similarly have been argued to be less vulnerable to predation because they conceal nest contents from visually oriented predators (Collias and Collias 1984). We found that daily predation rates were significantly lower for enclosed than open-cup nests for the group of species we studied. This difference provides another potential explanation for the prevalence of this nest type in southern regions, but it raises the question of why all open-cup nesting species do not build such nests, given the clear fitness advantages from reduced predation. This is an interesting question that deserves more attention.

Among all species, breeding generally began at the onset of the rainy season in October, peaked in early November, and ended in late December and early January. Timing of breeding may reflect responses to the rainy season and its influence on patterns of food availability (Marchant 1960, Lack 1968, Wunderle 1982) for egg formation (Perrins 1970) or for nestlings and fledglings (Lack 1968). However, direct research is needed to determine the extent of variation in the availability of different food types and its influence on differences in timing of breeding in these species (Noske and Franklin 1999).

Breeding season duration varied across species and averaged around two months. However, our estimates are based on all nests across three years due to limited sample sizes within years. As such, these season lengths may be slight overestimations because seasons start earlier or end later in different years related to weather differences (TEM, pers. obs.). The turdids and emberizids exhibited the longest breeding seasons, while flycatchers generally had the shortest breeding seasons. In general, breeding season lengths were comparable to those found in north temperate areas of the same but northern equivalent latitude (Ricklefs 1966). This result is particularly interesting because it indicates that the small clutch sizes of species in this community are not explained by long breeding seasons that allow more opportunities to renest, a commonly invoked explanation for small clutch sizes of southern birds (see review by Martin 1996).

Mean clutch sizes varied across species but were markedly smaller at our site than for related species in north temperate regions (Martin et al. 2000). Our estimates are similar to those reported for other southern South American passerines (Mason 1985, Yom-Tov et al. 1994) and for related tropical species (Moreau 1944, Skutch 1985). Clutch size differed among nest types, with larger clutches in cavity-nesting species than other species, an observation that has been noted in other systems (Martin and Li 1992, Martin 1995). Relatively larger clutch sizes have been noted especially in species such as nonexcavators that rely on the availability of natural and previously excavated sites (Martin and Li 1992, Martin 1993). As nonexcavators, House Wrens and Buff-browed Foliage-gleaners may produce relatively larger clutches to offset the costs of limited breeding opportunities due to limited availability of existing cavities (Martin 1993). However, clutch sizes among species were also correlated with variation in nest predation (Skutch 1949, Slagsvold 1982, Martin et al. 2000), which is influenced by nest type (Martin 1995). Clutch size was not related to duration of the breeding season among species within this community, further demonstrating that season length cannot explain the smaller clutch sizes of southern species.

Incubation and nestling period lengths varied substantially, with period lengths of some species almost twice the length of those of other species. High predation risk may favor faster development of young to offset costs of time-dependent mortality, yielding shorter periods in species with greater predation risk (Bosque and Bosque 1995, Martin 2002, Remeš and Martin 2002). Indeed, daily predation rates were negatively correlated with incubation period duration across species, but were not related to nestling or overall period lengths. However, nest predation during the incubation period in our study community did not differ from north temperate regions in general, while incubation period lengths were longer than in north temperate relatives, indicating that nest predation cannot explain latitudinal differences in developmental period durations (Martin 2002).

Biparental care was observed in all species; however, participation in incubation and feeding of nestlings differed between males and females 
among species. Variation in nest attentiveness may be explained by differences in how incubating parents balance the needs of the developing embryos with their own nutritional requirements (Conway and Martin 2000, Deeming 2002). However, nest attentiveness of species with female-only incubation in this community was consistently lower than in north temperate regions (Martin 2002). The generally lower nest attentiveness in this sample is typical of tropical and southern hemisphere birds with female-only incubation and may explain long incubation periods in these regions (Martin 2002).

Nestling feeding rates differed among species; they were highest in flycatchers and cavitynesting species and lowest in turdids and emberizids. Interspecific differences in nestling feeding rates may be influenced by environmental pressures such as nest predation (Skutch 1949, Martin et al. 2000). Parental activity at the nest may be constrained by predation risk if diurnal predators use parental behavior to locate nests (Skutch 1949). Indeed, nestling feeding rates were negatively correlated with predation risk in this group of species.

In summary, our study revealed wide variation in reproductive traits and breeding strategies within a subtropical southern hemisphere bird community. These traits, by and large, were more similar to those seen in related tropical birds than in related north temperate birds (Martin 1996). Causes of this geographical variation remain unclear and are in need of further study. Nest predation was the primary cause of nesting mortality at our site and may be an important selective pressure that drives interspecific differences in clutch size, nest type, and nest placement (Skutch 1949, Martin 1995, Martin et al. 2000). Nest predation may also influence nesting period lengths both directly through pressure on offspring growth and development rates and indirectly through its influence on parental behaviors such as nest attentiveness and nestling feeding rates. Yet, nest predation cannot explain why clutch sizes were smaller, developmental periods were longer, and nest attentiveness was lower than in related north temperate birds (Martin et al. 2000, Martin 2002). Clearly, other environmental sources of selection, such as adult mortality (Martin et al. 2000, Martin 2004), need to be explored to understand broad geographic variation in breeding biology and life history strategies.

\section{ACKNOWLEDGMENTS}

We gratefully acknowledge numerous field assistants and Mauricio Torres and Alina Niklison for their Spanish translation of the abstract. We are extremely grateful to the Laboratorio de Investigaciones Ecológicas de las Yungas (LIEY), Dra. Patricia Marconi, and El Rey National Park staff for logistical support of the work in Argentina. This work was supported by grants to TEM from the National Science Foundation (DEB-9707598, DEB9900343, and DEB-0543178), the U.S. Geological Survey Biological Resources Discipline, and the International Program of the U.S. Fish and Wildlife Service. Preparation of the manuscript was supported by a Department of Education Graduate Assistance in Areas of National Need (GAANN) Fellowship to RDB and a Department of Education GAANN Fellowship and National Science Foundation Graduate Research Fellowship to SKA.

\section{LITERATURE CITED}

BIANCHI, A. 1981. Las precipitaciones en el noroeste argentino. Instituto Nacional de Tecnologia Agropecuaria, Salta, Argentina.

Bosque, C., AND M. T. Bosque. 1995. Nest predation as a selective factor in the evolution of developmental rates in altricial birds. American Naturalist 145:234-260.

Brown, A. D. 1995. Fenología y caída de hojarasca en las selvas montanas del Parque Nacional El Rey, Argentina, p. 93-102. In A. D. Brown and H. R. Grau [EDS.], Investigacion, conservación y desarrollo en selvas subtropicales de montana. Universidad Nacional de Tucumán, Tucumán, Argentina.

CABrerA, A. L. 1976. Regiones fitogeográficas Argentinas, p. 1-85. In W. F. Kugler [ED.], Enciclopedia Argentina de agricultura y jardines. Editorial ACME S.A.C.I., Buenos Aires, Argentina.

Cabrera, A. L., And A. Willink. 1980. Biogeografia de America Latina. Organization of American States, Washington, DC.

Chalukian, S. C. 1991. Regeneración, sucesión y plantas invasoras en un bosque de Yungas, Salta, Argentina. M.Sc. thesis, Universidad Nacional, Heredia, Costa Rica.

Collias, N. E., AND E. Collias. 1984. Nest building and bird behavior. Princeton University Press, Princeton, NJ.

Conway, C. J., AND T. E. Martin. 2000. Evolution of passerine incubation behavior: influence of food, temperature, and nest predation. Evolution 54:670-685.

DeEming, D. C. 2002. Behavior patterns in incubation, p. 63-99. In D. C. Deeming [ED.], Avian incubation: behavior, environment and evolution. Oxford University Press, Oxford, UK.

FISCHER, A. G. 1960. Latitudinal variations in organic diversity. Evolution 14:64-81.

Ghalambor, C. K., And T. E. Martin. 2001. Fecundity-survival trade-offs and parental risktaking in birds. Science 292:494 497. 
GraU, H. R. 2000. Regeneration patterns of Cedrela lilloi (Meliaceae) in northwestern Argentina subtropical montane forests. Journal of Tropical Ecology 16:227-242.

Hensler, G. L., And J. D. Nichols. 1981. The Mayfield method of estimating nesting success: a model, estimators and simulation results. Wilson Bulletin 93:42-53.

Hines, J. E., AND J. R. SAUER. 1989. Program CONTRAST: a general program for the analysis of several survival or recovery rate estimates. U.S. Fish and Wildlife Service General Technical Report 24, Washington, DC.

Kulesza, G. 1990. An analysis of clutch size in NewWorld passerine birds. Ibis 132:407-422.

LACK, D. 1968. Ecological adaptations for breeding birds. Methuen, London.

MAJOR, R. E. 1991. Breeding biology of the Whitefronted Chat Ephthianura albifrons in a salt marsh near Melbourne. Emu 91:236-249.

MARCHANT, S. 1960. The breeding of some S.W. Ecuadorian birds. Ibis 4:349-382.

MARTIN, T. E. 1987. Food as a limit on breeding birds: a life-history perspective. Annual Review of Ecology and Systematics 18:453-487.

Martin, T. E. 1988. Processes organizing opennesting bird assemblages: competition or nest predation? Evolutionary Ecology 2:37-50.

MARTIN, T. E. 1993. Evolutionary determinants of clutch size in cavity-nesting birds: nest predation or limited breeding opportunities? American Naturalist 142:937-946.

Martin, T. E. 1995. Avian life history evolution in relation to nest sites, nest predation, and food. Ecological Monographs 65:101-127.

MARTIN, T. E. 1996. Life history evolution in tropical and south temperate birds: what do we really know? Journal of Avian Biology 27: 263-272.

MARTIN, T. E. 2002. A new view for avian life history evolution tested on an incubation paradox. Proceedings of the Royal Society of London Series B 269:309-316.

Martin, T. E. 2004. Avian life-history evolution has an eminent past: does it have a bright future? Auk 121:289-301.

Martin, T. E., R. D. Bassar, S. K. Bassar, J. J. Fontaine, P. Lloyd, H. A. Mathewson, A. M. Niklison, And A. Chalfoun. 2006. Lifehistory and ecological correlates of geographic variation in egg and clutch mass among passerine species. Evolution 60:390-398.

Martin, T. E., AND G. R. Geupel. 1993. Nestmonitoring plots: methods for locating nests and monitoring success. Journal of Field Ornithology 64:507-519.

Martin, T. E., AND C. K. GHalambor. 1999. Males feeding females during incubation: required by microclimate or constrained by nest predation? American Naturalist 6:131-139.

MARTIN, T. E., AND P. LI. 1992. Life history traits of open vs. cavity-nesting birds. Ecology 73:579-592.

Martin, T. E., P. R. Martin, C. R. Olson, B. J. Heidinger, And J. J. Fontaine. 2000. Parental care and clutch sizes in North and South American birds. Science 287:1482-1485.

Martin, T. E., C. Paine, C. J. Conway, And M. HocHACHKA. 1996. BBIRD field protocol. Montana Cooperative Wildlife Research Unit, Missoula, MT.

Mason, P. 1985. The nesting biology of some passerines of Buenos Aires, Argentina. Ornithological Monographs 36:954-972.

MAYFIELD, H. 1961. Nesting success calculated from exposure. Wilson Bulletin 73:255-261.

MAYFIELD, H. 1975. Suggestions for calculating nest success. Wilson Bulletin 87:456-466.

Moreau, R. E. 1944. Clutch size: a comparative study, with special reference to African birds. Ibis 86:286-347.

Noske, R. A., And D. C. Franklin. 1999. Breeding seasons of land birds in the Australian monsoonal tropics: diverse responses to a highly seasonal environment. Australian Biology 12:72-90.

ONIKI, Y. 1979. Is nesting success of birds low in the tropics? Biotropica 11:60-69.

PERRINS, C. M. 1970. The timing of birds' breeding seasons. Ibis 112:242-255.

REMEŠ, V., AND T. E. MARTIN. 2002. Environmental influences on the evolution of growth and developmental rates in passerines. Evolution 56:2505-2518.

RICKLEFS, R. E. 1966. The temporal component of diversity among species of birds. Evolution 20:235-242.

RiCKLEFS, R. E. 1969. An analysis of nesting mortality in birds. Smithsonian Contributions to Zoology 9:1-48.

Ridgely, R. S., AND G. TudoR. 1989. The birds of South America. 1. The oscine passerines. University of Texas Press, Austin, TX.

Ridgely, R. S., AND G. TudoR. 1994. The birds of South America. 2. The suboscine passerines. University of Texas Press, Austin, TX.

RoFF, D. A. 1992. The evolution of life histories: theory and analysis. Chapman and Hall, New York.

SkUTCH, A. F. 1949. Do tropical birds rear as many young as they can nourish? Ibis 91:430-455.

SkUTCH, A. F. 1985. Clutch size, nesting success, and predation rates on nests of Neotropical birds, reviewed. Ornithological Monographs 36:575-594.

Slagsvold, T. 1982. Clutch size variation in passerine birds: the nest predation hypothesis. Oecologia 54:159-169.

SLAGSVOLD, T. 1989. On the evolution of clutch size and nest size in passerine birds. Oecologia 79:300-305.

SNOW, D. W. 1978. The nest as a factor determining clutch-size in tropical birds. Journal of Ornithology 119:227-230.

SPSS. 2003. SPSS for Windows. SPSS, Inc., Chicago.

STEARnS, S. C. 1992. The evolution of life histories. Oxford University Press, Oxford, UK.

WUNDERLE, J. W., JR. 1982. The timing of the breeding season in the Bananaquit (Coereba flaveola) on the island of Grenada, W. I. Biotropica 14:124-131.

Yom-Tov, Y., M. I. Christie, And G. J. Iglesias. 1994. Clutch size in passerines of southern South America. Condor 96:170-177. 